\section{Visión Electrónica Más que un estado sólido \\ https://doi.org/10.14483/issn.2248-4728}

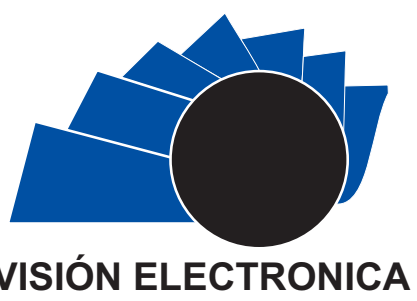

A CASE - STUDY VISION

\title{
TDT DVB-T2 signal coverage in rural zones
}

\author{
Cobertura de la señal TDT DBV-T2 en zonas rurales
}

\section{INFORMACIÓN DEL ARTICULO}

Historia del articulo

Enviado: 04/09/2018

Recibido: 23/09/2018

Aceptado: 17/10/2018

\section{Keywords:}

DTT network planning,

Okumura-Hata model,

Propagation losses,

Propagation model,

SUI model.

\section{Palabras clave:}

Planificación red TDT,

Modelo Okumura-Hata,

Pérdidas de propagación,

Modelo de propagación, Modelo SUI.

\author{
Diana Acosta-Peña ${ }^{1}$ Elvis Eduardo Gaona-García ${ }^{2}$ \\ Juan Pablo Oviedo-Perdomo ${ }^{3}$
}

\begin{abstract}
This paper analyzes the Digital Terrestrial Television (DTT) signal coverage in the department of Cundinamarca, comparing two propagation models: Okumura-Hata, and Stanford University Interim (SUI). These models were selected because they allow the calculation of propagation losses in the UHF band and do not require greater precision in the cartographic information to estimate diffraction losses. As a result, was obtained that the selected models are close to the field measurements, in a range of 8 to $12 \mathrm{~dB}$. In addition, adjustments were made to the propagation models obtaining the losses estimation in the signal propagation. The models were evaluated applying statistical criteria such as: correlation coefficient, mean square error and standard deviation. Finally, it was determined that the two models fit easily to the values obtained in the field measurements; however, the difference presented by the Okumura-Hata model was smaller in comparison with the SUI model; but the latest one allowed a better fit to the propagation model than the Okumura-Hata model.
\end{abstract}

\section{RESUMEN:}

En este artículo se realiza el análisis de cobertura de la señal de Televisión Digital Terrestre (TDT) en el departamento de Cundinamarca, comparando dos modelos de propagación: Okumura-Hata, e Interino de la Universidad de Stanford (SUI). Estos modelos fueron seleccionados debido a que permiten calcular las pérdidas de propagación en la banda UHF y no requieren mayor precisión en la información cartográfica para estimar las pérdidas por difracción. Como resultado se obtuvo que los modelos seleccionados se acercan al valor obtenido, en las mediciones de campo, en un rango de 8 a $12 \mathrm{~dB}$. Adicionalmente, se efectuaron ajustes a los modelos de propagación obteniendo la estimación de pérdidas en la propagación de la señal. Los modelos se evaluaron aplicando criterios estadísticos como: coeficiente de correlación, error medio cuadrado y desviación estándar. Finalmente, se determinó que los dos modelos se ajustan fácilmente a los valores obtenidos en las mediciones de campo; sin embargo, la diferencia presentada por el modelo Okumura-Hata resultó menor en comparación con el modelo SUI; pero este último permitió realizar un mejor ajuste al modelo de propagación que el modelo Okumura-Hata.

\footnotetext{
BSc. (c) In Telecommunications Engineering, Universidad Distrital Francisco José de Caldas, Colombia. Current position: Universidad Distrital Francisco José de Caldas, Colombia. E-mail: dacostap@,correo.udistrital.edu.co ORCID: https://orcid.org/0000-0002-7395-453X

2 BSc. In Electronic Engineering, Universidad Distrital Francisco José de Caldas, Colombia. Specialization in Mobile Telecommunications, Colombia. MSc. In Information and communications sciences, Universidad Distrital Francisco José de Caldas, Colombia. PhD. In Engineering, Universidad Distrital Francisco José de Caldas, Colombia. Current position: Universidad Distrital Francisco José de Caldas, Colombia. E-mail: egaona@udistrital.edu.co ORCID: https://orcid.org/o000-0001-5431-8776

${ }^{3}$ BSc. In Electronic Engineering, Universidad Distrital Francisco José de Caldas, Colombia. Current position: Universidad Distrital Francisco José de Caldas, Colombia. E-mail: jpoviedo@,correo.udistrital.edu.co ORCID: https://orcid.org/0000-0002-1576-6821

Cite this article as: D. Acosta-Peña, E. E. Gaona-García and J. P. Oviedo-Perdomo, "TDT DVB-T2 signal coverage in rural zones", Visión electrónica, algo más que un estado sólido, vol. 1, no. 2, Special edition, july-december 2018. DOI revista: https://doi.org/10.14483/issn.2248-4728
} 


\section{Introduction}

Since the 1970s, television has become the most impactful mass media generating large-scale cultural change. This impact has been compounded by the transformation and arrival of new technologies for transmitting and receiving image and sound, such as digital television. This technology represents the most radical technological change in the television industry, after the appearance of color TV.

In 2009 began a gradual implementation of digital television in some of the country's areas, starting in the main cities, which should end in 2019 with a coverage of one hundred percent of the population that currently has analog television coverage, seeking the called "analog blackout". Considering the above, Colombia has carried out multiple network designs that offer coverage to the national territory under the standard Digital Video Broadcasting Second Generation Terrestrial -DVB T2-, being Bogotá one of the cities that has total coverage thanks to the 5 installed stations: Suba and Santa Librada operated by National Private Channels Consortium (CCNP by its Spanish acronym), Calatrava, El Cable and Cruz Verde operated by National Radio and Television of Colombia (RTVC by its Spanish acronym). Thanks to these stations, there is also coverage in the municipalities adjacent to Bogotá.

This paper analyzes and compares two propagation models using measurements made at different points in the municipalities of Chía, Cota and Cajicá, using acquired information regarding the areas of expansion in the Land Use Plan (POT ${ }^{4}$ by its Spanish acronym) of each one of the municipalities,[1-3]. A correction is made to the propagation models for the design of an efficient coverage network, so that when correcting and/or modelling a radio link considering the characteristics of the trajectory between the transmitting station and the receivers, the feasibility of implementing the network in terms of system capacity and costs is evident, [4-5].

The following paper is divided into the sections described below:

Section 2 focuses, as a state of the art, on the background to this kind of research. Section 3 presents the materials and methods that evidence the analysis of the data and the Okmura-Hata and SUI propagation models application. Section 4 shows the proposed propagation models comparison and correction. Section 5 presents the results discussion; and section 6 contains the research conclusions.

\section{State of the art}

Several projects have been developed that propose the analysis of the quality of the television signal in different localities of Bogota, making measurements in open and closed environments, this with the objective of using propagation models applicable to urban environments in which propagation losses are analyzed, [6-8]; with the software assistance, are designed and proposed scenarios that improve coverage and make adjustments to the models. It is evident that the public channels have an inclination to the market without interest to the user, but the necessary coverage tests are not always carried out, [9-11].

On the other hand, some investigations present studies and analysis of the propagation of a Digital Terrestrial Television network under the DVB-T standard -applied in Colombia- to determine the way in which the interaction with DVB-T2-supported DTT occurs, [12], both in fixed and mobile reception in Bogotá D.C., performing coverage simulations under three different transmitter configuration scenarios, analysing at the same time the impact on climate change generated by the technological waste resulting from the implementation of the DTV in Colombia, [13-15]. The coexistence of DTT and LTE signals that are deployed in Colombia and in the South American region has also been taken into account, [16-17]. In another way, in Colombia different types of transmission have been carried out due to technological changes looking for which one can be adapted according to geography, [1819]. In the same sense, there have been discussions of the policies that seek to regulate the transmission of DTT, [20-21]. The developed tests are based on software that allows the power levels simulation needed to have a good coverage in closed environments, [2224]. On the other hand, in South American countries several studies have been developed on the application of propagation methods, which allows to better estimate the radio coverage, [25]. In other cases the Okumura-Hata and Stanford University models are proposed in order to determine the main factors affecting each of the models, [26-27].

Finally, it is reported also investigations where there are field strength measurements of the DTT signal with the ISDB-Tb standard, locating the shadow areas suggesting alternative solutions through the use of Gap Filler transmitters, being diffraction propagation model the most prominent, [28-29].

\subsection{Propagation Models}

In the network design for a certain coverage, it must be taken into account that there are reflection, diffraction

Plan de Ordenamiento territorial, Land Use Plan 
and dispersion parameters that the signal suffers on the way from the transmitter to the receiver, [30-31]. When modelling the propagation of this signal, it is also necessary to take into account the environment (urban, rural or suburban), height of transmitters, working frequency. In short, propagation models can be classified as deterministic, empirical and semideterministic, [32-35].

The Xia-Bertoni model describes the propagation in large cities of signals located in the UHF band (from $300 \mathrm{MHz}$ to $3 \mathrm{GHz}$ ), [36]. This model takes into account the terrain profile and buildings to estimate losses; other models are: Cost 231 Walfisch-Ikegami model, and the Stanford University interim model, [3739].

One of the best-known and applied propagation models for estimating losses in urban environments is the one described in the Okumura-Hata compilation. This model allows the estimation in suburban and rural environments from base data of urban environments, [40-42]. It represents the urban propagation loss as a function of the operating frequency (f) 150 a 1500 $\mathrm{MHz}$ ), distance between transmitter and receiver, antenna height and a correction factor(hre)of the receiving antenna height which will depend on the size of the area in question, [43-44] .

The loss equation is:

$L_{50}($ urbano $)(d B)=69.55+26.16 \log f_{c}-13.82 \log h_{t e}-a\left(h_{r e}\right)+(44.9-6.55 \log d)$

-In the above equation, some restrictions must be taken into account:

$\cdot 150 \mathrm{MHz}<\mathrm{f}_{\mathrm{c}}<1500 \mathrm{MHz}$

$\bullet 30 \mathrm{~m}<\mathrm{h}_{\mathrm{te}}<200 \mathrm{~m}$

Where:

\section{$f_{c}$ :Carrier frequency in $\mathrm{MHz}$}

$h_{t e}$ :Transmitting antenna height in meters for a range of 30 to 300 meters

$h_{r e}$ : Receiving antenna height in the range of 1 to 10 meters

$a\left(h_{r e}\right)$ :Correction factor for the effective height of the mobile depending on the type of service area.

$d$ : Distance between transmitter and receiver in Kilometres

The new variable, with respect to Okumura, is the correction factor for effective height of the mobile $a\left(h_{r e}\right)$ this factor is dependent on the coverage area. Different $a\left(h_{r e}\right)$ values can be defined for different propagation environments. The $a\left(h_{r e}\right)$ value for small and medium cities is:

$$
a\left(h_{r e}\right)=\left(1.1 \log f_{c}-0.7\right) a\left(h_{t e}\right)-\left(1.56 \log f_{c}-0.8\right)
$$

For a suburban environment the equation to calculate $a\left(h_{r e}\right)$ is:

$$
a\left(h_{r e}\right)=L_{50}(\text { urbano })-2\left[\log \left(f_{\frac{f}{28}}\right)\right]^{2}-5.4
$$

For rural areas the following equation is used to calculate $a\left(h_{r e}\right)$ :

$$
\left.a\left(h_{r e}\right)=L_{50} \text { (urbano }\right)-4.78\left(\log f_{c}\right)^{2}+18.33 \log f_{c}-40.94
$$

The propagation model developed by the IEEE in conjunction with Stanford University Interim model is an empirical model that requires each city area characterization, according to a terrain type. The SUI model is divided for three types of terrain, i.e. A, B and C.

Type A is associated with maximum trajectory loss and is suitable for mountainous terrain of moderate to dense vegetation densities, [45-47].

Type $\mathrm{B}$ is characterized by adapting to any of the mostly flat terrain with moderate to high density of trees or mountainous terrain with a slight density of trees.

Type $\mathrm{C}$ is associated with minimum trajectory loss and applies to flat terrain with a slight density of trees.

The equation of loss per trajectory with correction factors is as follows:

$$
L(d B)=A+10 \gamma \log _{10}\left(\frac{d}{d_{0}}\right)+S, \text { para } d>d_{0}
$$

Where:

$$
\gamma=a-b h_{b}+\frac{c}{h_{b}}
$$

$H b$ : is the transmitting station height $s$ : is a shading factor

$y$ : is the loss exponent per trajectory, whose constants $a$, $b$ and $c$ depend on the type of terrain to be studied; for the case study in this paper it corresponds to Type A terrain, see Table 1.

\begin{tabular}{|c|c|}
\hline Parameter & Type A terrain \\
\hline $\mathrm{a}$ & 4.6 \\
\hline $\mathrm{b}$ & 0.0075 \\
\hline $\mathrm{c}$ & 12.6 \\
\hline $\mathrm{S}$ & 10.6 \\
\hline
\end{tabular}

Table 1. Stanford Model Parameter, [14]. 
Consequently, the present research is relevant since it seeks to propose a propagation model that describes more precisely the behavior of the measurements obtained for the selected scenario, through the analysis of the data, as well as the correction to the proposed models that allow improving the coverage on the 28 and 30 channels, taking into account that so far no studies have been carried out in the areas that were chosen.

\section{Materials and methods}

\subsection{Data Acquisition and Processing}

The data acquisition is performed by measuring the radiation power at the previously selected points in the Google Earth software, this process is done with the

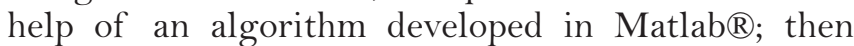
proceeds to make the necessary calculations for the Okumura -Hata and Interim model of Stanford University propagation models, after obtaining the behavior of each model proceeds to make the calculation that allows to propose the correction to the models using the curve Fitting Matlab® tool.

The measurements are performed with teams from the District University Francisco José de Caldas; these were performed at different points in three municipalities in the department of Cundinamarca previously selected in Google Earth program. The used equipment consists of a Tectronix RSA306 spectrum analyzer, an AARONIA hyperlog4025 directional antenna, a GSTAR IV GPS and a screen, these supported in an designed algorithm in Matlab ${ }^{\circledR}$ for the data acquisition of the radiation power; later the necessary calculations are made for the Okumura-Hata and the Interin Model of Stanford University propagation models, after observing the behavior of each model the calculations are made, allowing proposing the correction to the models using the Matlabß curve Fitting tool.

\begin{tabular}{|l|l|l|}
\hline Description & Value & Unit \\
\hline PIRE BTS & 24013.14194 & $\mathrm{~W}$ \\
\hline PTx BTS & 73.8044 & $\mathrm{DBm}$ \\
\hline Antenna Gain Tx & 12.45 & $\mathrm{dBi}$ \\
\hline Antenna Gain Rx & 5 & $\mathrm{~dB}$ \\
\hline $\begin{array}{l}\text { Center Frequency 28 } \\
\text { Channel }\end{array}$ & 557 & $\mathrm{Mhz}$ \\
\hline $\begin{array}{l}\text { Center Frequency 30 } \\
\text { Channel }\end{array}$ & 569 & $\mathrm{Mhz}$ \\
\hline System loss Rx & 3.5 & $\mathrm{dBm}$ \\
\hline System loss Tx & 2.42 & $\mathrm{~dB}$ \\
\hline Height BTS & 58 & $\mathrm{M}$ \\
\hline Measurement height & 10 & $\mathrm{M}$ \\
\hline
\end{tabular}

Table 2. Calatrava station parameters, [49].
For the propagation analysis of this paper, the Calatrava station located on the Suba hill is taken as transmission reference; the study is carried out on channels 28 and 30 assigned to RTVC, [48]. Table 2 below describes the transmitting station transmission parameters.

The selected points for the Calatrava station study are shown in Figure 1.

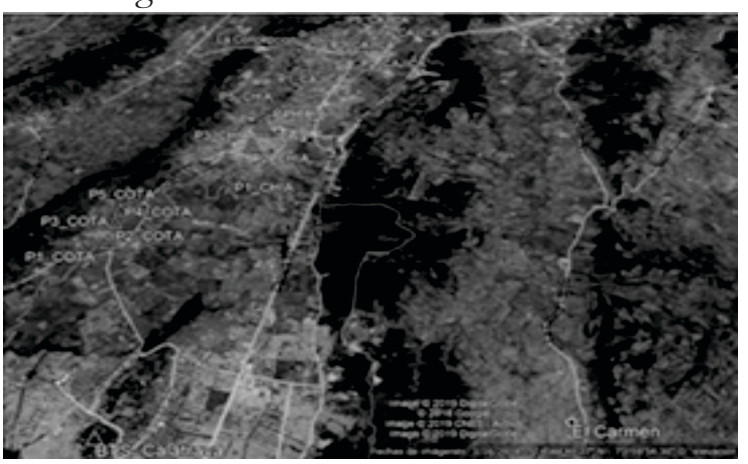

Figure 1. Measurement points referenced to the Calatrava station $4^{\circ} 44^{\prime} 36.88^{\prime \prime N}, 74^{\circ} 4^{\prime} 29.38$ "W.

Source: own.

The data obtained in the measurements are listed in Table 3.

\begin{tabular}{|r|r|r|}
\hline $\begin{array}{r}\text { BTS } \\
\text { Distance } \\
\text { (m) }\end{array}$ & $\begin{array}{r}\text { Channel 28 } \\
\text { Power Level } \\
\text { (dB) }\end{array}$ & $\begin{array}{r}\text { Channel 30 } \\
\text { Power Level } \\
\text { (dB) }\end{array}$ \\
\hline 8430 & $-26,2271039$ & $-26,61224533$ \\
\hline 8600 & $-51,7271039$ & $-56,71224533$ \\
\hline 10300 & $-75,5271039$ & $-79,81224533$ \\
\hline 10900 & $-43,6271039$ & $-62,96224533$ \\
\hline 11000 & $-44,8071039$ & $-42,80224533$ \\
\hline 12200 & $-75,6971039$ & $-77,62224533$ \\
\hline 14300 & $-75,5271039$ & $-79,81224533$ \\
\hline 15700 & $-26,2271039$ & $-26,61224533$ \\
\hline 17200 & $-23,1271039$ & $-26,11224533$ \\
\hline 18700 & $-36,8271039$ & $-41,11224533$ \\
\hline 20400 & $-33,2271039$ & $-33,91224533$ \\
\hline 21800 & $-45,0971039$ & $-46,89224533$ \\
\hline 22800 & $-36,1171039$ & $-61,16224533$ \\
\hline 24400 & $-54,5671039$ & $-49,11224533$ \\
\hline 25100 & $-40,7271039$ & $-41,01224533$ \\
\hline
\end{tabular}

Table 3. Measurement data for channels 28 and 30. Source: own.

The obtained graphs in the analysis of the selected points data are shown below, Figures 2 and 3:

Receiving power vs. Distance Graphs

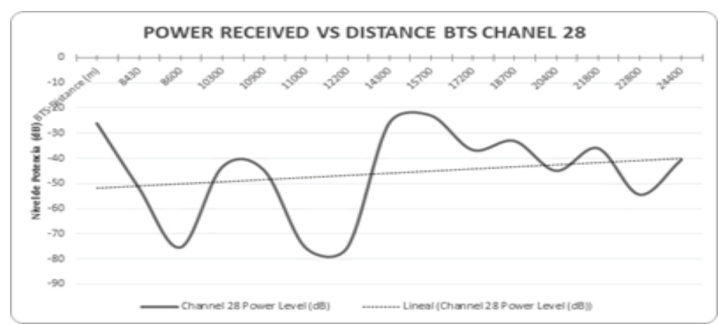

Figure 2. Calatrava channel 28, received power vs distance ratio. Source: own 


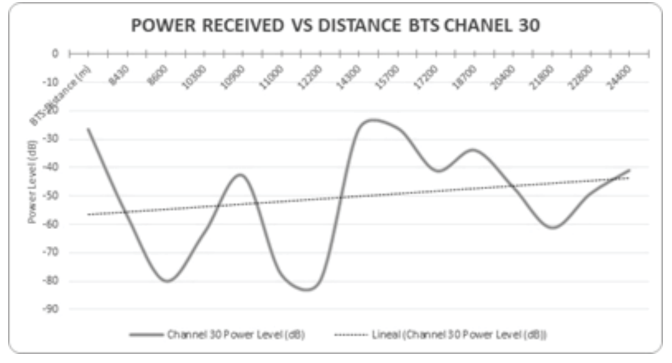

Figure 3. Calatrava channel 30, received power vs distance ratio. Source: own

\subsection{Free Space Propagation}

Due to the reception power, and taking into account that free space losses are ideal when ignoring interferences or possible obstructions, only the frequency and distance of the link is used, this is adopted as a reference for the propagation loss calculation as shown in Figures 4 and 5 :

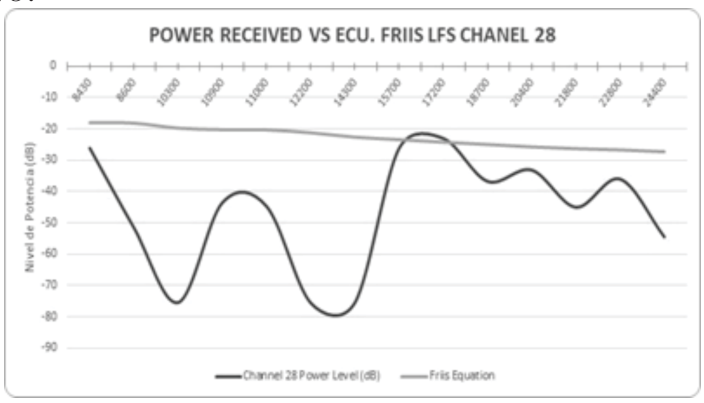

Figure 4. Channel 28, expected power ratio from free space model. Source: own.

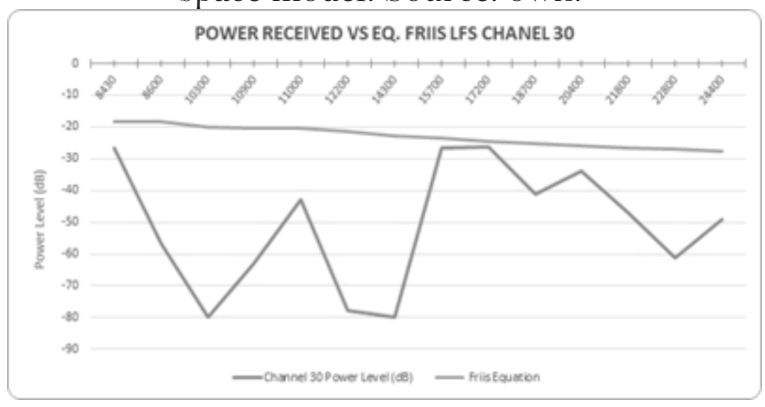

Figure 5. Channel 30, expected power ratio from free space model. Source: own.

As can be seen in Figures 4 and 5 , there is a difference of plus or minus $9 \mathrm{~dB}$ in principle and that increases at the end compared to the actual power obtained in the measurements.

\subsection{Okumura-Hata Propagation}

Based on the empirical formulation explained above, it can be seen that there is a unique correction pattern in the loss analysis. This pattern is the antenna correction factor for this case and taking into account that a small area is studied and established using equation (2):

$a\left(h_{r e}\right)=\left(1.1 \log f_{c}-0.7\right) a\left(h_{t e}\right)-\left(1.56 \log f_{c}-0.8\right)=18,1208$

This correction factor depends on the height (hre)at which the measurements were made. The data obtained by applying the Okumura-Hata model and the corresponding Friis equation to the measurement trajectories are shown below, taking into account that the measurements are made at a height of $10 \mathrm{~m}$ at the receiver.

Subsequently, the Okumura - Hata calculation for rural areas was performed by establishing the use of equation (4).

Then, in Figures 6 and 7, the behaviour of the expected power through Okumura-Hata and the SUI model is compared with the actual measurements taken point by point with reference to the Calatrava station.

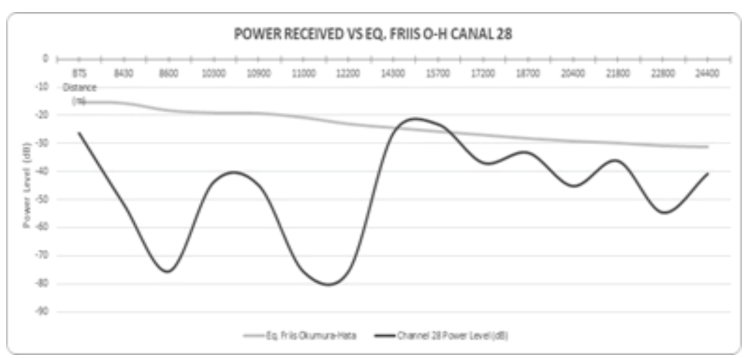

Figure 6. Calatrava cannel 28, Expected power ratio from Okumura-Hata model. Source: own.

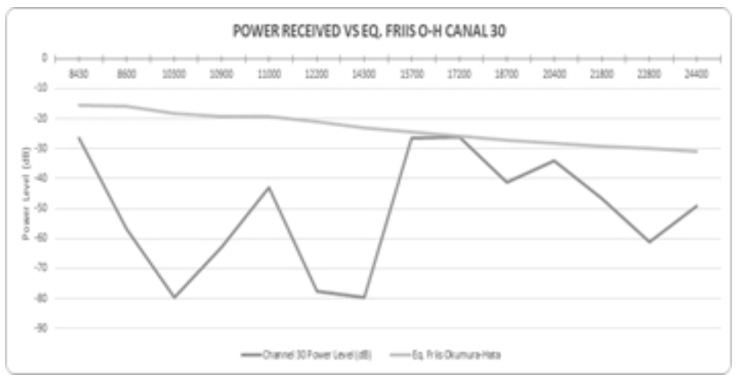

Figure 7. Calatrava cannel 30, Expected power ratio from Okumura-Hata model. Source: own.

From the expected power graphical analysis with Okumura-Hata as the loss estimation model; there is a difference between the theorical data and the actual measurement data of plus or minus $8 \mathrm{~dB}$ for channel 28 over the base station and a difference between 8 and 10 $\mathrm{dB}$ for channel 30. When comparing the obtained data with Okumura-Hata and the free space model the difference between 8 and $10 \mathrm{~dB}$ with the actual data is maintained. 
In order to evaluate the performance of the loss estimation model, some statistical significance criteria were analyzed, which are shown in Table 4.

\begin{tabular}{|l|l|l|}
\hline Statistical criteria for the Okumura-Hata model \\
\hline Criteria & CH 28 & CH 30 \\
\hline Correlation Coefficient & 0,0588 & $-0,2322$ \\
\hline Quadratic Mean Error & 801,14 & 725,32 \\
\hline Covariance & 5,728 & $-24,11$ \\
\hline Variance & 322,37 & 314,1 \\
\hline Standard Deviation & 17,954 & 17,72 \\
\hline Structural Similarity Index & $-0,0344$ & 0,0164 \\
\hline
\end{tabular}

Table 4. Calatrava channels 28 and 30, statistical criteria for Okumura-Hata model. Source: own.

\subsection{Stanford University(SUI) Propagation}

The Interim Model of Stanford University defines three different scenarios to calculate the basic propagation loss. The scenario that fits the conditions in which the present research was performed corresponds to category C: Flat areas with very low vegetation density. With the constants provided by the Stanford study corresponding to type C terrain, it is obtained according to equation (5):

$$
\begin{gathered}
L(d B)=A+10 \gamma \log \left[\frac{d}{d_{0}}\right]+S \\
A=4.6 \\
S=10.2
\end{gathered}
$$

Being,

$d$ : the distance between the transmitting station and the receiving antenna

$d 0=100 \mathrm{~m}$

$S$ : corresponds to the shading effect

$r$ :is the loss per trajectory exponent that depends on the constants a, b and c, which are listed in Table 1. of this paper.

Figures 8 and 9 compare the expected power behaviour by means of SUI with the actual point-to-point measurements taken with reference to Calatrava station.

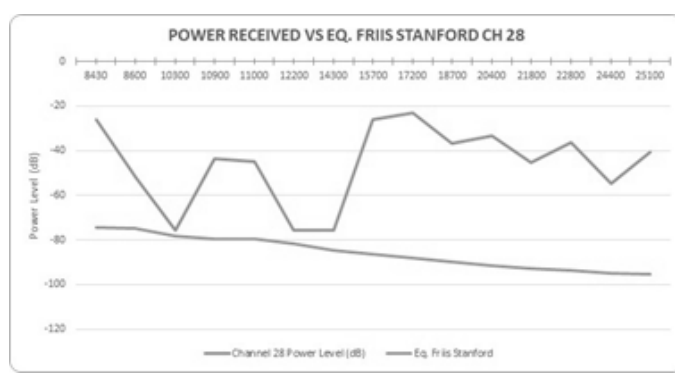

Figure 8. Calatrava channel 28, expected power ratio from SUI model. Source: own.

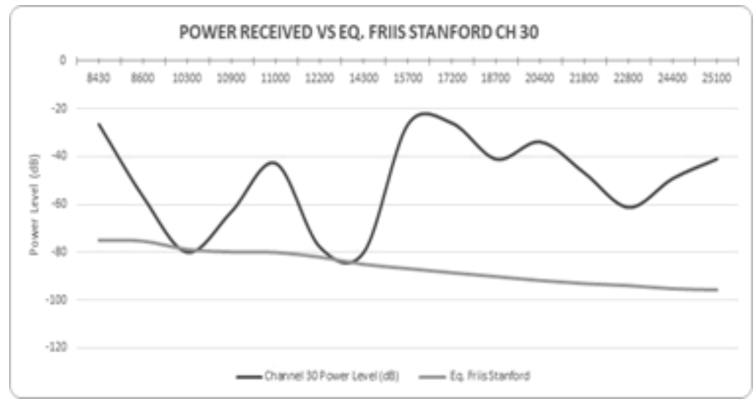

Figure 9. Calatrava channel 30, expected power ratio from SUI model. Source: own.

When comparing the Okumura-Hata and SUI models, it is observed that there is a margin of $48 \mathrm{~dB}$ that separates them in principle; however, they maintain a similar slope ending in $54 \mathrm{~dB}$. Table 5 . shows the statistical criteria for this model:

\begin{tabular}{|l|l|l|}
\hline \multicolumn{3}{|l|}{ Statistical criteria for the Stanford model } \\
\hline Criteria & CH 28 & CH 30 \\
\hline $\begin{array}{l}\text { Correlation } \\
\text { Coefficient }\end{array}$ & 0,0588 & $-0,2322$ \\
\hline Quadratic Mean Error & 19000000 & 17200000 \\
\hline Covariance & 7,527 & $-31,6848$ \\
\hline Variance & 304,6 & 324,7 \\
\hline Standard Deviation & 17,454 & 18,031 \\
\hline $\begin{array}{l}\text { Structural Similarity } \\
\text { Index }\end{array}$ & $-0,003$ & 0,023 \\
\hline
\end{tabular}

Table 5. Calatrava channels 28 and 30, statistical criteria for SUI model. Source: own.

\section{Models comparison and correction}

Figures 10 and 11 show the two models studied and the measurements taken for channels 28 and 30 on the Calatrava station, respectively: 


\section{RECEIVED POWER VS DISTANCE BTS CHANEL 28}

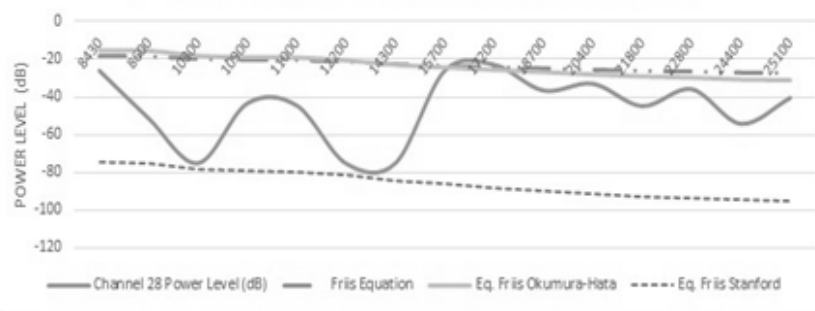

Figure 50. Calatrava channel 28, compilation of Okumura-Hata and SUI models vs. measured data. Source: own.

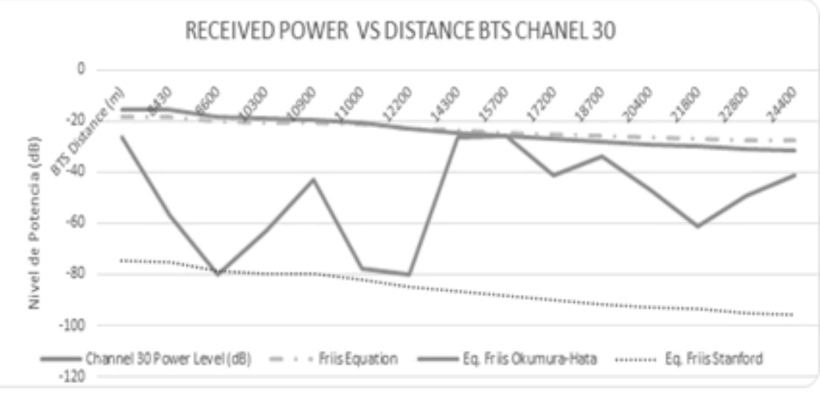

Figure 11. Calatrava channel 30, compilation of Okumura-Hata and SUI models vs. measured data. Source: own.

The correction of the propagation models is carried out through the Matlabß software, where changes were made to the constants provided by the models in such a way that they conform to the maximum expected power levels.

\subsection{Okumura-Hata Model Correction}

The correction to the Okumura -Hata equation is made taking into account that this is a rural area, as evidenced in equations 7 and 8 channel 28 and channel 30 respectively, the modified constant is $(-4.78)$ which is underlined, with the data obtained from this correction the power levels are calculated as shown in Figures 12 and 13.

$L_{50}($ urbano $)(d B)=69.55+26.16 \log f_{c}-13.82 \log h_{t e}-a\left(h_{r e}\right)+(44.9-6.55 \log d)$

$$
L=L_{50}(\text { urbano })-\underline{4.78} *\left(\log f_{c}\right)\left(\log f_{c}\right)^{2}+18.33 * \log f_{c}-40.94
$$

$L=(69,55+(26,16 * \log (569))-(13,82 * \log (58))-8,7421+(44,9-(6,55 * \log (58))) *$

$$
\begin{gathered}
\left.\log \left(\frac{d}{1000}\right)\right)-\underline{3,8} *(\log 569)(\log 569)^{2}+18.33 * \log 569-40.94 \\
L=(69,55+(26,16 * \log (569))-(13,82 * \log (58))-8,7421+(44,9-(6,55 * \log (58))) * \\
\left.\log \left(\frac{d}{1000}\right)\right)-\underline{3,68} *(\log 569)(\log 569)^{2}+18.33 * \log 569-40.94
\end{gathered}
$$

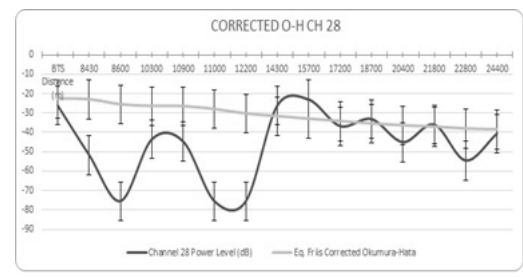

Figure 13. Calatrava channel 28, comparison of received power with corrected Okumura-Hata equation. Source: own.

The new model does not fit exactly to the actual power curve as evidenced in graphs 13 and 14 below, this is because the initial data have a noticeable difference with the final data, this for both channels.

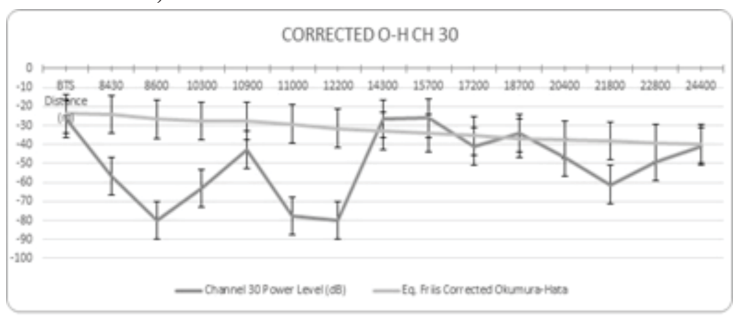

Figure 14. Calatrava channel 30, comparison of received power with corrected Okumura-Hata equation. Source: own.

In order to evaluate the accuracy level of the corrected model, the statistical significance criteria are reevaluated, as can be seen in Table 6:

\begin{tabular}{|l|l|l|}
\hline \multicolumn{3}{|l|}{ Statistical Criteria for the Corrected O-H Model } \\
\hline Criteria & CH 28 & CH 30 \\
\hline Correlation Coefficient & 0,0608 & $-0,2322$ \\
\hline Quadratic Mean Error & 527,4 & 730,4 \\
\hline Covariance & 5,881 & $-17,91$ \\
\hline Variance & 315,5 & 319,2 \\
\hline Standard Deviation & 17,764 & 17,454 \\
\hline Structural Similarity Index & $-0,0354$ & 0,0126 \\
\hline
\end{tabular}

Table 6. Calatrava channels 28 and 30, statistical criteria for corrected Okumura-Hata. Source: own.

\subsection{Stanford University (SUI) Model Correction}

Next, the correction to the SUI model is presented by making variations to the underlined constant and adding a value to the end of the equation as shown in equation 9.

$$
\begin{gathered}
L(\boldsymbol{d} B)=\boldsymbol{A}+\underline{\mathbf{1 0}} * \boldsymbol{B} * \log \left(\frac{\boldsymbol{x}}{\mathbf{1 0 0}}\right)+\boldsymbol{C} \\
L(d B)=A+\underline{0,624} * B * \log \left(\frac{x}{100}\right)+C+\underline{41,88}
\end{gathered}
$$


The graphs in Figures 15 and 16 shown below illustrate the correction for each channel.

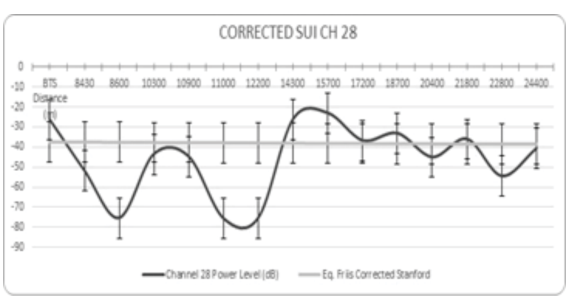

Figure 15. Calatrava channel 28, comparison of received power with corrected SUI. Source: own.

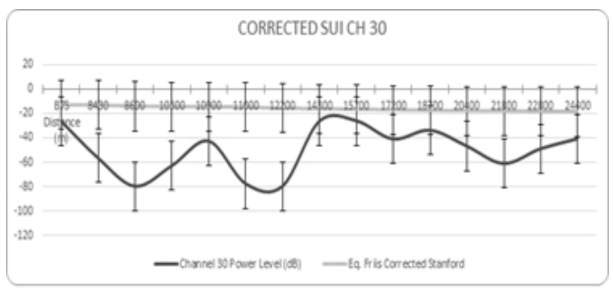

Figure 16 . Calatrava channel 30, comparison of received power with corrected SUI. Source: own.

In addition, the quadratic mean error was evaluated, which makes it possible to estimate the difference between the estimator and what it estimates. Next, the corrected model and its respective graphs are presented with respect to the real power values received in each point and for each channel, Figures 17 and 18, Table 7.

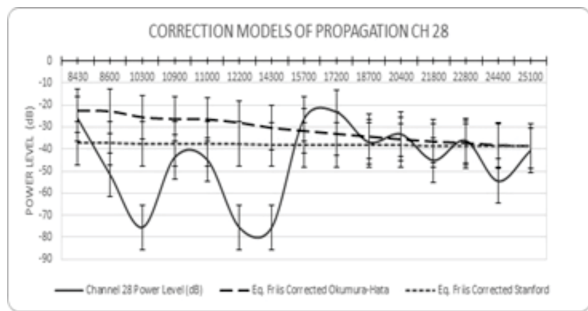

Figure 17. Calatrava channel 28, comparison of received power with corrected Okumura-Hata and Stanford models. Source: own.

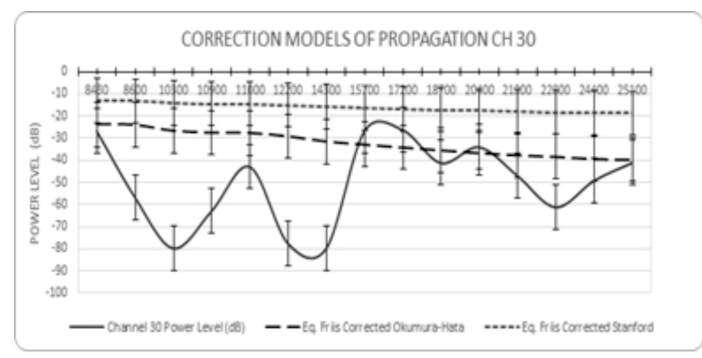

Figure 18. Calatrava channel 30, comparison of received power with corrected Okumura-Hata and Stanford models. Source: own.

\begin{tabular}{|c|c|c|c|c|}
\hline $\begin{array}{c}\text { Statistical } \\
\text { Criteria }\end{array}$ & $\begin{array}{c}\text { CORREC } \\
\text { TED } \\
0-\mathrm{H} \mathrm{CH} \\
28\end{array}$ & $\begin{array}{c}\text { CORREC } \\
\text { TED } \\
0-\mathrm{H} \mathrm{CH} \\
30\end{array}$ & $\begin{array}{c}\text { CORREC } \\
\text { TED } \\
\text { Stanford } \\
\text { Ch } 28\end{array}$ & $\begin{array}{c}\text { CORREC } \\
\text { TED } \\
\text { Stanford } \\
\text { Ch } 30\end{array}$ \\
\hline $\begin{array}{c}\text { Correlation } \\
\text { Coefficient }\end{array}$ & 0,0608 & $-0,2322$ & 0,0588 & $-0,232$ \\
\hline $\begin{array}{c}\text { Quadratic } \\
\text { Mean } \\
\text { Error }\end{array}$ & 527,4 & 730,45 & 356,1 & $\begin{array}{l}1,509 E \\
+07\end{array}$ \\
\hline $\begin{array}{c}\text { Covariance } \\
\text { Coviance }\end{array}$ & 5,8818 & $-17,91$ & 0,469 & $-8,555$ \\
\hline $\begin{array}{l}\text { Variancis } \\
\text { Standard } \\
\text { Deviation }\end{array}$ & 17,764 & 17,866 & 17,207 & 17,897 \\
\hline Structural \\
$\begin{array}{c}\text { Similarity } \\
\text { Index }\end{array}$ & $-0,0354$ & 0,0126 & $-0,016$ & 0,004 \\
\hline
\end{tabular}

Table 7. Calatrava channels 28 and 30, statistical criteria for corrected Okumura-Hata and Stanford models. Source: own.

\section{Discussion of results}

The obtained results in the measurements show that the reception power in the points that are near the mountain slope in the municipality of Cota is low due to the reflection that is presented, on the other hand it can be determined that the obtained power in the measurements in the most distant points is better and tends to stabilize.

It can be observed that channel 28, which corresponds to the regional channel (Canal Capital) transmitted from Bogotá, has a power similar to the channel 30, which corresponds to the public channel (Canal Institucional TV), being this an advantage for Canal Capital since it can be spread in the region through DTT.

When analyzing the propagation models with respect to the made corrections it can be observed that the model that shows better performance for channel 28 is the interim model of Stanford University, this because the calculations development takes into account the aspect of terrain and the correction is simpler to perform.

\section{Conclusions}

The performance of the selected propagation models was analyzed using the measurement results of the Calatrava station in the city of Bogotá and the coverage towards the region of Cundinamarca specifically Cota, Chía and Cajicá, whose scenarios present different 
frequency, deployment, environment and terrain profile characteristics (2 different channels were analyzed in each municipality). The results shown in this paper indicate that the propagation model should be chosen taking into account the deployment scenario, cartographic information, transmitter height and terrain profile. In order to perform the appropriate and more precise model development, it is necessary to develop a semi-empirical model, which involves taking measurements and thus propose a better adjustment.

From the statistical analysis performed on each model before and after the correction it can be determined that the two models could be adjusted to the propagation need. However, due to the terrain profile there is a high error.

Thanks to the corrections made and the curves fit, it was possible to reduce the quadratic mean error to an average $34 \%$ for the Okumura -Hata model on channel 28 that corresponds to Canal Capital, on the other hand this same model increases the error for channel 30 that corresponds to Canal Institucional TV.

Developing the same analysis for the Interim Model of Stanford University (SUI) it was possible to determine that for channel 28 the quadratic mean error could be reduced by an average of $99.98 \%$ and for channel 30 the error was reduced by an average of $12.8 \%$.

Thus, it can be said that for channel 28 the two models present a very good fit and although for channel 30 the correction of the mean error is lower, the model that performs best is the Interim Model of Stanford University.

Because the propagation models allow to obtain an estimated power level approximation that is received, these depend on the transmission radius of the transmitting station; taking into account the above, not all models have the same performance due to the fact that the conditions on which they are considered do not take into account all the same variables in such way that they add or eliminate variables mainly with respect to the cartography and the terrain profile. Consequently, when developing coverage projects, it must be taken into account that all models have a margin of error that affects the desired transmission performance.

When making a correction to an empirical propagation model this becomes a semi-empirical model that provides more tools to determine basic parameters more accurately for the location of a link, some of these parameters are the transmission power, radiation angles, loss estimation in the environment, diffraction losses, fading, diffraction etc.

\section{Acknowledgements}

The authors would like to thank the Scientific Research and Development Center (CIDC by its acronym in Spanish) for their financial support for the research project entitled "Methodology for the design and planning of digital terrestrial television networks in urban and rural environments in Colombia", the Telecommunications Research Group of the District University (GITUD by its acronym in Spanish) and the Basic Sciences Research Group (SciBas by its acronym in Spanish).

\section{References}

[1] Consejo Municipal de Chía, "Acuerdo 100 POT 2016 Chia”, 2016. [Online]. Available at: h t $t$ p s : / / w w w . c h i a cundinamarca.gov.co/index.php/ley-1712transparencia/pot-2016

[2] Secretaria de Planeación Municipal, "Plan Básico de Ordenamiento Territorial PBOT”, 2018. [Online]. Available at: http://www.cotacundinamarca.gov.co/Transparencia/Planeaci onGestionyControl/POT\%20COTA/1\%20Documento\%20Resumen.pdf

[3] Secretaria de Planeación Municipal, "Acuerdo 16 de 2014 PBOT Cajicá", 2014. [Online]. Available at:

https://www.ccb.org.co/content/download/2 7593/564422/file/Cajica\%20PBOT\%20Cajic a\%20Rev\%202014.pdf

[4] J. García, O. Rodríguez and J. Castillo, "Desempeño de Modelos de Propagación en Comunicación Móvil para la zona de Caldas Parte 1: Modelos para áreas urbanas”, 2002. [ O n line $]$. A v a i l a ble a t: http://www.docentes.unal.edu.co/jcgarciaa/d ocs/Papers/ID016.pdf

[5] I. F. Chacho Prado and H. V. Zamora Castro, "Recomendación De Ubicación De Transmisores Para Una Cobertura Optima De Televisión Digital Terrestre En La Ciudad De Cuenca, Basada En Un Modelo De Propagación Ajustado", thesis, Universidad de Cuenca, Ecuador, 2016. 
[6] K. N. Florido Angarita, "Medición de la Calidad de la Señal de los Canales de Televisión Pública en la Localidad de Ciudad Bolívar", thesis, Universidad Distrital Francisco José de Caldas, Colombia, 2018.

[7] L. F. Pedraza, D. M. Ballesteros and H. Vaca, "Estudio De Modelos De Propagación En El Entorno De La Universidad Distrital Francisco José De Caldas", Revista Visión Electrónica, vol. 4, no. 2, 2010, pp. 77-87. https://doi.org/10.14483/22484728.276

[8] E. A. López Salamanca, "Metodología para planificación de redes de Televisión Digital Terrestre en Colombia”, thesis Msc., Universidad Distrital Francisco José De Caldas, Colombia, 2016.

[9] C. Moreno, A. Marín, J. Sierra and F. Gil, "Diseño y Análisis De Red De Televisión Digital Terrestre (TDT) Para Medellín Antioquia”, Rev. en Telecomunicaciones e Informática, vol. 1, no. 1, 2011 , pp. 31-48.

[10] A. Barrios Ulloa, "Análisis Comparativo de Modelos de Propagación para el Enlace Descendente en Redes Hspa+ en Áreas Urbanas y Suburbanas. Caso Estudio: Barranquilla", thesis MSc., Universidad Tecnológica de Bolívar, Colombia, 2015. https://doi.org/10.24054/16927257.v32.n32. $\underline{2018.3029}$

[11] D. García Ramírez, "El modelo de televisión regional en Colombia: canales públicos bajo los parámetros del mercado", Signo y Pensamiento, vol. 34, no. 66,2015, p. 28. https://doi.org/10.11144/Javeriana.syp34$\underline{66 . \mathrm{mtrc}}$

[12] J. A. Acosta Torres and C. A. Ortega Arrieta, "Modelo conceptual para la transmisión de contenidos interactivos, con base en el estándar DVB-T2 aplicado en Colombia”, thesis, Universidad de Cartagena, 2014.

[13] L. C. Ariza, "Estudio de propagación de una red de DTV terrestre bajo el estándar DVB-T con recepción fija y móvil en el escenario metropolitano de la ciudad de Bogotá D.C., Colombia”, thesis MSc., Universidad Nacional de Colombia, 2012.
$[14]$

A. Expósito Cano, "Ampliación De Cobertura TDT Mediante Herramientas De Planificación y Campaña De Medidas", thesis, Universidad Politécnica De Cartagena, Colombia, 2014.

[15] N. Y. Zambrano, N. A. García, E. J. Ramírez, M. L. Cabrera and J. R. Uzcátegui, "Nuevo Modelo Para Predicción De Pérdidas De Propagación En Sistemas De Televisión Digital Abierta”, Revista ingeniería al día, vol. 4, no. 1, 2018, pp. 38-62.

[16] J. A. Ribadeneira Ramírez, "Planificación de Frecuencias para Televisión Digital Terrestre (TDT) en Sudamérica”, thesis, Universidad Politécnica de Valencia, 2016. http://doi.org/10.4995/Thesis/10251/63669

[17] D. Escudero, "Implementación En Matlab De Una Herramienta De Planificación Wi-fi Para Entornos De Interior", thesis, Universidad de Granada, 2014.

[18] L. Bahamón, "Televisión Digital en Colombia”, thesis, Universidad Tecnológica De Pereira, Colombia, 2011.

[19] J. H. Amaya Valencia and J. E. Arévalo Peña, "Eficiencia de sistemas multiantena MU-MIMO por simulaciones de radiopropagación”, IEEE Colombian Conference on Communications and Computing (COLCOM), 2017 , pp. 1-8. https://doi.org/10.1109/ColComCon.2014.6 $\underline{860417}$

[20] D. García Ramírez and W. Zambrano Ayala, "Transición digital de la televisión en Colombia: mercado, propiedad y pluralismo", 2016. [Online]. Available at: https://www.javeriana.edu.co/unesco/humanidad esDigitales/ponencias/pdf/IV_07.pdf

[21] A. G. Caram, A. Labandera and G. Marín, "Mediciones y Modelo de Cobertura para Televisión Digital Terrestre", thesis, Universidad de la República, Uruguay, 2014.

[22] E. Castellanos, J. Talero, J. D. Rugeles and H. Boada, "Análisis de propagación electromagnética en espacios cerrados: Herramienta software en Matlab para predicción y simulación”, Revista Colombiana de Tecnologías de Avanzada, no. 6, no. 2, 2005, pp. 130-137. 
[23] TES AMERICA, "Informe Medición TDT Cali”, 2016. [Online]. Available at: https://www.icesi.edu.co/i2t/teleco/images/ Anexos Success/Anexo\%2016.\%20Informe\% 20de\%20medicin\%20TDT-Cali.pdf

[24] J. R. Fernández, "Estudio y propuesta de modelo de propagación para TDT en Lima y su implementación en un software de estimación de cobertura desarrollado usando Matlab", thesis, Universidad Nacional De Ingeniería Lima, Perú, 2012.

[25] J. I. Morales, "Cálculo de Radio Enlace en la banda GSM-850 utilizando Modelo de Propagación Okumura-Hata”, 2012. [Online]. A va i l a ble a t : https://www.academia.edu/5051509/C $\% \mathrm{C} 3 \%$ A1lculo de Radio Enlace en la banda GSM850_utilizando_Modelo_de_Propagaci\%C3\% B3n_Okumura-Hata

[26] A. P. Garcia, H. Ortega, A. Navarro and A. H. Rodríguez, "Effect of terrain on electromagnetic propagation in urban environments on the Andean region, using the COST231-Walfisch-Ikegami model and GIS planning tools", Twelfth International Conference on Antennas and Propagation, 2003. https://doi.org/10.1049/cp:20030066

[27] R. A. Quintana, R. Bordón López, and S. M. Sánchez, "Estudio comparativo de los modelos de propagación de canal inalámbrico", Revista de Ingeniería Electrónica, Automática y Comunicaciones, vol. 34, no. 1, 2013, pp. 12-26.

[28] Á. V. Saca Tene, "Análisis de Cobertura del Sistema de Televisión Digital Terrestre para el Canal 47 en la Ciudad de Quito", thesis, Universidad Politécnica Salesiana, Ecuador, 2013.

[29] A. O. Pazmiño, O. G. Martínez, J. A. Ribadeneira, J. R. Jácome and J. J. Gavilanes, "Analysis of propagation models for digital terrestrial television (DTT), under the ISDB$\mathrm{Tb}$ standard in cities of Ambato and Latacunga, Ecuador", J. Sci. Res. Rev. Cienc. e Investig., vol. 3, no. CITT2017, 2018, pp. 84-90. https://doi.org/10.26910/issn.25288083vol3issCITT2017.2018pp84-90

[30] L. F. Pedraza Martínez, C. A. Hernández Suárez and D. M. Ballesteros Larrotta, "Análisis
Experimental Para Un Modelo De Propagación De La Telefonía Móvil De La Universidad Militar," Ciencia e Ing. Neogranadina, vol. 19, no. 2, 2009, pp. 45-58. https://doi.org/10.18359/rcin.289

[31] S. Vidal Beltrán, E. A. Degollado Rea and J. L. López Bonilla, "Modelo de propagación simplificado para LTE en la frecuencia de 2.1 GHz”, Revista Electrónica Nova Scientia, vol. 9, no. 19,2017 https://doi.org/10.21640/ns.v9i19.917

[32] V. Barreda Artés, "Estudio, diseño e instalación de un centro emisor de TDT con gapfillers", thesis, Universidad Politécnica de Cataluña, 2009.

[33] J. López, C. García, D. Gómez, and N. Cardona, "Planificación y Optimización De Redes DVBT Para La Provisión De Servicios Locales y Móviles En Colombia”, Gerencia Tecnológica Informática, vol. 9, no. 23, 2011 , pp. 111-123.

[34] D. Tello Guillamón, "Planificación Radio de Sistemas TDT: Estudio Práctico en un Entorno Rural", thesis, Universidad Politécnica de Cataluña, 2009.

[35] Y. I. Carreño, H. Ortega Boada and A. Paolo García, "Desarrollo del modelo de propagación andino-uis", Revista Gerencia Tecnológica Informática, vol. 4, no. 8, 2005, pp. 29-30.

[36] Á. D. Pinto, J. M. Torres, A. S. García Bello, N. A. Pérez and J. R. Uzcátegui, "Modelo para Estimación de Pérdidas de Propagación en Sistema de Televisión Digital Abierta", Revista de Ingeniería Electrónica, Automática y Comunicaciones, vol. 2, 2017, pp. 1815-5928.

[37] J. J. Giménez Gandía, J. López Sánchez, D. Gómez and N. Cardona, "Modelos de propagación radio para redes de TDT móvil en la banda UHF”, Revista $S \& T$, vol. 9, no. 18, 2011 , pp. 9-27.

[38] S. Beciez, N. Flores and C. Pérez, "Aplicación de Modelos de Propagación en Sistemas Inalámbricos de Área Extendida WWAN", thesis, Instituto Politécnico Nacional Escuela Superior de Ingeniería Mecánica y Eléctrica, 2013. 
[39] M. A. Molina Reino, "Modelo De Propagación Para La Ciudad De Cuenca (Ecuador), En Redes Wlan Operando En 2.4 GHz y $5.8 \mathrm{GHz}$, En Ambientes Exteriores", thesis MSc., Escuela Superior Politécnica del Litoral, 2017.

[40] S. Gallego, "Comparación de modelos teóricos para el análisis de las pérdidas por difracción múltiple de la señal radioeléctrica con medidas experimentales en entornos urbanos", thesis, Universidad Politécnica De Cartagena, 2008.

[41] J. M. Zamanillo, C. Pérez-vega and I. Zamanillo, "Modelo de propagación para exteriores mejorado para frecuencias de $50 \mathrm{MHz}$ a 1.2 $\mathrm{GHz}$, thesis, Universidad de Cantabria, 2009.

[42] F. J. García Rueda, "Modelos de propagación para comunicaciones móviles $4 \mathrm{G}$ y $5 \mathrm{G}$ ", thesis, Escuela Técnica Superior De Ingeniería Y Sistemas De Telecomunicación, 2014.

[43] R. E. Chávez Sánchez, "Ajuste Estadístico a Modelos De Propagación Para Redes Móviles", thesis MSc., Universidad Distrital Francisco José de Caldas, Colombia, 2015.

[44] T. S. Rappaport, "Wireless Communications Principles and Practice", USA: Prentice-Hall, Inc, 2002, pp. 107-110.

[45] L. F. Pedraza Martínez, "Modelo de propagación para un entorno urbano que identifica las oportunidades espectrales para redes móviles de radio cognitiva Modelo de propagación para un entorno urbano que identifica las oportunidades espectrales para redes móviles de radio cognitiva", thesis $\mathrm{PhD}$., Universidad Nacional de Colombia, 2016.

[46] R. Bordón López, R. Alonso Quintana and S. Montejo Sánchez, "Evaluación de modelos de propagación de canal inalámbrico", Revista Cubana de Ingeniería, vol. 3, no. 1, 2012, pp. 53-62.

[47] A. Navarro Cadavid and C. Andredy Ardila, "Ajuste estadístico de modelos de propagación de señal usando medidas de la ciudad de Cali”, Ingenium, vol. 6, no. 11,2016 , p. 11 . https://doi.org/10.21774/ing.v6i11.58

[48] ANTV, "Descubre Ciudades y Municipios que ya cuentan con la señal TDT", 2016. [Online]. Available at: https://www.tdtcolombia.tv/
[49] ANTV, "Mediciones de Cobertura TDT", 2016. [ O n l ine e. A v a i l a ble a t : https://www.antv.gov.co/index.php/tdt/medi ciones-de-cobertura-tdt 